\title{
Effect of the Quality of Institutions on the Tax Structure in West African Economic and Monetary Union Countries (WAEMU)
}

\author{
Aichatou Mourfou ${ }^{1, *}$, Idrissa Mohamed Ouedraogo ${ }^{2}$ \\ ${ }^{1}$ Department of Economics and Management, University Thomas Sankara, Ouagadougou, Burkina-Faso \\ ${ }^{2} \mathrm{PhD}$ School, University Aube Nouvelle, Ouagadougou, Burkina-Faso
}

Email address:

aichatoumourfou@yahoo.fr (A. Mourfou)

*Corresponding author

\section{To cite this article:}

Aichatou Mourfou, Idrissa Mohamed Ouedraogo. Effect of the Quality of Institutions on the Tax Structure in West African Economic and Monetary Union Countries (WAEMU). Journal of Business and Economic Development. Vol. 6, No. 1, 2021, pp. 1-11. doi: $10.11648 /$ j.jbed.20210601.11

Received: January 5, 2021; Accepted: January 18, 2021; Published: January 25, 2021

\begin{abstract}
The objective of this paper is to analyze the effect of the quality of institutions on the different types of tax revenues, in particular on the total tax revenue, the direct tax revenue, the domestic indirect tax revenue and the trade tax revenue. The econometric analysis used the Pooled Mean Group (PMG) estimator over the period from 1996 to 2015. The results of the estimates show that in the WAEMU zone, the quality of institutions has a positive and significant effect on all types of tax revenues except for trade tax revenue. These results are robust because they do not change according to the different indicators used to measure the quality of institutions. Furthermore, overall, GDP per capita positively and significantly affects total and indirect domestic tax revenue, while it has a negative effect on direct tax revenue. Trade openness has a positive and significant effect on all types of tax revenues, except for indirect domestic tax revenue. The share of agriculture has a positive and significant effect on all types of revenue except trade tax revenue. Inflation has a negative and significant effect on all types of tax revenues. The share of natural resources and the size of the informal sector show mixed results.
\end{abstract}

Keywords: Total Tax Revenue, Direct Tax Revenue, Domestic Indirect Tax Revenue, Trade Tax Revenue, Quality of Institutions, PMG, WAEMU

\section{Introduction}

One of the major challenges facing most developing countries is undoubtedly the increased mobilization of tax revenues. In the particular case of the countries of the WAEMU, especially Benin, Burkina Faso, Côte d'Ivoire, Guinea-Bissau, Mali, Niger, Senegal and Togo, the issue of tax resource mobilization is much more crucial, as these economies are characterized by significant financing needs to ensure their development. Aware of this situation, these countries have, since the 1990s, adopted tax reforms with a view to improving tax revenue mobilization.

However, these reforms seem ineffective because the tax revenue is still low in these countries compared to the rest of the world. Indeed, according to data from the African Development Bank (ADB, 2018), the Union's total fiscal revenue rate is 14.97 as a percentage (\%) of the Gross Domestic Product (GDP) as an annual average. over the period 1996-2015; which is below the 20\% threshold which is the minimum tax revenue rate suggested in the context of multilateral surveillance of WAEMU countries. In addition, it is lower, not only than the average fiscal revenue of the countries of the Organization for Economic Co-operation and Development (OECD) which is equal to $33.4 \%$ of the GDP, but also and above all, that of the countries Africa which stands at around $16 \%$ of GDP over the same period.

These facts, which reflect the ineffectiveness of the tax reforms of the $1990 \mathrm{~s}$, militate in favor of further reforms to increase the capacity to mobilize tax resources. Thus, the identification of the determinants of the tax revenue in these countries is fundamental.

Theories of political economy postulate that the quality of 
institutions determines both the total level of tax revenue collected and the component of tax revenue [17, 18]. According to this work, good institutional quality improves the mobilization of internal rather than external tax revenue. In reality, domestic tax revenues (direct and indirect) require greater voluntary taxpayer compliance and excellent administrative capacity more than other types of taxes.

From this perspective, what is the effect of the quality of institutions on the different types of tax revenue in WAEMU countries? The objective of this article is to analyze the effect of the quality of institutions on the different types of tax revenues, among others, on total tax revenues, direct tax revenues, domestic indirect tax revenues and trade tax revenues. Based on the work of previous authors, the hypothesis is that a good quality of institutions is more favorable to internal than external taxation.

In the remainder of the article, we first present a synthesis of the literature, then the methodology and variables used, and finally the results and their interpretation, followed by a conclusion.

\section{Literature}

According to public choice theory, an institutional framework characterized by good democratic quality promotes increased mobilization of internal tax revenues. Indeed, democracies can be considered as regimes with strong political competition which can lead to a socially optimal political choice in terms of taxation [10]. In fact, politicians are maximizing the vote and will choose the political tax that maximizes the welfare of a large group of voters This legitimizes tax policies and improves the intrinsic motivation of the taxpayer. This will result in a greater collection of taxes, especially internal taxes (direct and indirect) and low volatility of tax revenues.

In addition, the theoretical literature studies the tax structure of non-democratic countries. Wintrobe considers that dictatorships can collect as much tax revenue as they want, as long as they have sufficient power because these regimes generally use physical representation in collecting public revenue $[37,38]$. Dictatorships are primarily accountable to a smaller group such as the military who are most likely to form political opposition. Also, this auteur points out that tax structures are inefficient in this type of regime, unlike in democratic regimes, because the taxes collected are used for the political leaders' own ends, either for their own consumption or to strengthen their power.

Empirically, on a sample of developed and developing countries from 1980 to 1997, the study by Tanzi and Davoodi show a negative influence of corruption on domestic tax revenues (direct and indirect) and, not significant for corruption on trade taxes [36]. These authors also report that countries which adopted value added tax (VAT) earlier tend to have a lower level of corruption and higher VAT productivity afterwards. However, these conclusions should be considered very provisional as they are based on descriptive statistics. Moreover, the direction of causality is not obvious. Mahdavi, in his analysis of developing countries from 1973 to 2002, observes that corruption hinders the mobilization of taxes on international trade [27]. Attila, Chambas, and Combes on a set of 125 countries, on the other hand, show that corruption improves trade tax revenues and therefore corruption hinders the tax transition (shift from door-to-door taxation to internal taxation) [5]. By determining the impact of trade liberalization on the tax structure in a panel of 97 developing countries for the period 1993-2012, Karimi et al. find that corruption has a negative effect on payroll taxes [21]. However, the use of a comprehensive system will make it possible to refine these results. This explains the insignificant effect of corruption on other types of tax (taxes on income, profits and capital gains, social security contributions, property taxes, internal taxes on goods and services, taxes on international trade).

Kenny and Winer report that conflicts, especially coups, are not relevant in explaining the tax structure [23]. These authors used a version of a political equilibrium model for different types of tax and non-tax revenues. However, their theoretical model did not include an explicit budget constraint. In their work on 39 sub-Saharan African countries and 85 developing countries respectively, Addison and Levin, on the one hand, and, Diarra, on the other hand challenge the findings of Kenny and Winer. Addison and Levin observe that political stability (peace) only has a positive effect on direct taxes because fiscal citizenship increases as the risk of conflict decreases [3]. However, Diarra points out that conflicts, on the one hand, reduce VAT revenues and, on the other hand, increase government oil revenues [14]. According to the latter, government oil revenues are easier to mobilize and less conflict-sensitive, so that countries put more emphasis on these revenues during conflict periods to compensate for the loss of other categories of government revenue.

In sum, the various studies show that countries with good institutional quality (democratic regime, political stability, low level of corruption, etc.) rely more on domestic tax revenues (especially direct and indirect taxes). Indeed, as already mentioned above, domestic tax revenues require greater voluntary compliance by taxpayers, which requires very good institutional quality more than other types of taxes [23]. However, two limitations emerge from this literature: the absence of empirical studies on the specific case of WAEMU countries and the lack of use of a composite index of institutional quality in the various investigations. Indeed, the different institutional factors each capture only one particular aspect of institutions, so a composite index of institutional quality is more relevant because it allows the multiple aspects of institutional quality to be taken into account simultaneously. The econometric analysis of the present research attempts to overcome these two limitations of the literature.

\section{Methodology}

In this section, estimation models, measurement of variables, expected signs, period of analysis, data sources and estimation techniques are presented. 


\subsection{Theoretical and Empirical Models}

Based on the fiscal model applied by Heller, it is assumed that the actual ratio of tax revenues to GDP $(T / Y)$ is a function of the desired ratio of tax revenues to GDP $(T / Y)^{*}$ and the availability of certain tax bases $(B)$ as well as the quality of institutions $(I)[16,27]$. That is to say,

$$
T / Y=f\left\{(T / Y)^{*}, B, I\right\}
$$

Equation (1) can be written as follows:

$$
\sum_{j=1}^{n}\left(T_{j} / Y\right)=\sum_{j=1}^{n} S_{j}=h\left\{1 / Y, \frac{F+L}{Y}, B, I\right\}
$$

Where $T_{j}$ is the revenue of the jth type of tax and $S_{j}=$ $\left(T_{j} / Y\right)$ is the share of the jth type of tax in the total production.

By specifying equation (2) in a panel and adopting the linear form according to the specific objectives of the research, the empirical equations to be estimated are as follows:

$$
\begin{aligned}
& \text { TPFT }_{i t}=\alpha_{0}+\alpha_{1} \text { wgi }_{i t}+\alpha_{2} \text { pibh }_{i t}+\alpha_{3} \text { agri }_{i t}+\alpha_{4} \text { resnat }_{i t}+\alpha_{5} \text { ouv }_{i t}+\alpha_{6} \text { inf }_{i t}+\alpha_{7} s i_{i t}+\varepsilon_{i t} \\
& \text { TPFD }_{i t}=\beta_{0}+\beta_{1} \text { ggi }_{i t}+\beta_{2} \text { pibh }_{i t}+\beta_{3} \text { agri }_{i t}+\beta_{4} \text { resnat }_{i t}+\beta_{5} \text { ouv }_{i t}+\beta_{6} i n f_{i t}+\beta_{7} s i_{i t}+\rho_{i t} \\
& \text { TPFI }_{i t}=\gamma_{0}+\gamma_{1} \text { wgi }_{i t}+\gamma_{2} \text { pibh }_{i t}+\gamma_{3} \text { agri }_{i t}+\gamma_{4} \text { resnat }_{i t}+\gamma_{5} \text { ouv }_{i t}+\gamma_{6} \text { inf }_{i t}+\gamma_{7} s i_{i t}++\sigma_{i t} \\
& \text { TPFC }_{i t}=\delta_{0}+\delta_{1} \text { wgi }_{i t}+\delta_{2} \text { pibh }_{i t}+\delta_{3} \text { agri }_{i t}+\delta_{4} \text { resnat }_{i t}+\delta_{5} \text { ouv }_{i t}+\delta_{6} i n f_{i t}+\delta_{7} i_{i t}++\tau_{i t}
\end{aligned}
$$

with TPFT, TPFD, TPFI and TPFC, respectively the rate of total fiscal revenue, the rate of direct fiscal revenue, the rate of domestic indirect fiscal revenue and the rate of trade fiscal revenue; $w g i$, the composite index of the quality of institutions; pibh, the logarithm of GDP per capita; agri, the share of agriculture in $\%$ of GDP; resnat, the share of natural resources in $\%$ of GDP; ouv, the openness of trade in \% of GDP; inf, , the inflation rate; $s i$, the size of the informal sector in $\%$ of GDP. $\alpha_{0}$, $\beta_{0}, \gamma_{0}$ and $\delta_{0}$ the respective constants of the different equations. $\alpha_{1}, \alpha_{2}, \alpha_{3}, \alpha_{4}, \alpha_{5}, \alpha_{6}$ and, $\alpha_{7}$ the respective coefficients of the different explanatory variables of equation (3). $\beta_{1}, \beta_{2}, \beta_{3}, \beta_{4}, \beta_{5}$, $\beta_{6}$ and, $\beta_{7}$ the respective coefficients of the different explanatory variables in equation (4). $\gamma_{1}, \gamma_{2}, \gamma_{3}, \gamma_{4}, \gamma_{5}, \gamma_{6}$ and, $\gamma_{7}$ the respective coefficients of the different explanatory variables in equation (5). $\delta_{1}, \delta_{2}, \delta_{3}, \delta_{4}, \delta_{5}, \delta_{6}$ and, $\delta_{7}$ the respective coefficients of the different explanatory variables of equation (6). $\varepsilon, \rho, \sigma$, and $\tau$ refer to the error terms of the equations to be estimated (3), (4), (5) and (6) respectively.

\subsection{Variables and Data Sources}

There are four (04) endogenous variables: the total tax revenue rate, the direct tax revenue rate, the domestic indirect tax revenue rate, and the trade tax revenue rate. The total tax revenue rate is equal to the ratio of total tax revenue (sum of direct taxes, indirect taxes, taxes on foreign trade and non-fiscal or parafiscal revenues) to income. The direct tax revenue rate is the ratio of direct tax revenue (which includes profit and income taxes) to income. The rate of domestic indirect tax revenue is the ratio of domestic indirect tax revenues (e.g., VAT and excise duties) to income. The trade tax revenue rate is the ratio of trade tax revenues (such as customs duties) to income.

As for the variables of interest, they are of two (03) types: a composite index of institutional quality constructed from the six (06) governance indicators of Kaufmann, Kraay and ZoidoLobaton (KKZ) ${ }^{1}$ of the World Bank (WB), a composite index of institutional factors obtained from the twelve (12) institutional quality indicators of the International Country

1 Appendix 1
Risk Guide (ICRG) ${ }^{2}$, a simple indicator of the quality of institutions measured by the polity2. The polity 2 index is between -10 and +10 and is based on the transparency of political participation, elections and constraints on the executive. The more the index tends towards -10 , the more autocratic the system is. On the other hand, the more it tends towards 10, the more democratic the system is. In accordance with the research hypotheses, a positive effect of the three indicators for measuring institutional quality is expected on total tax revenue, direct tax revenue and domestic indirect tax revenue, while a negative effect of these three indicators is expected on the rate of trade tax revenue.

The control variables concern the traditional determinants of the fiscal revenue, namely: the level of development of the country, the sectoral composition of income, in particular the share of agriculture and natural resources in GDP, the degree of openness, the inflation rate and the size of the informal sector.

The level of development is approximated by the logarithm of GDP per capita. The higher the GDP per capita, the higher the taxable potential and the easier it is to raise taxes [25]. Thus, the expected sign is positive for all types of revenue.

The share of agriculture in GDP is expected to have a negative effect on the different tax revenues. The agricultural sector is difficult to tax because of the predominance of subsistence activities and often dispersed production units [5,34].

The share of total natural resources (oil, natural gas, coal, mining and forestry resources) in GDP can have a positive effect on tax revenues because this sector generates significant revenues $[7,12]$. On the other hand, according to the "resource curse" theory referred to by Auty, resource-rich countries tend to neglect tax revenue mobilization because of the large rents in this sector $[6,35]$. Thus, the expected sign is ambiguous for all types of tax revenue.

The degree of openness measures the volume of trade (sum of imports and exports) with the rest of the world relative to GDP. An increase in the degree of openness should be accompanied by an increase in customs revenues and thus an improvement in the various rates of fiscal revenues, other things being equal [24,

2 Appendix 2 
29]. However, if this liberalization manifests itself in tariff reductions then tax revenue losses can be expected $[2,8]$. The expected sign is ambiguous for all types of tax revenues.

According to Botlhole, the costs of inflation to tax revenue mobilization can come from three sources [9]. Firstly, the presence of the Olivera-Tanzi effect, i.e., the negative effect of inflation on tax revenues in the presence of collection delays. Secondly, the exercise of the tax on certain products for which the tax rates were specific will not automatically adjust to inflation. Finally, the reduction in the tax base due to the fact that households, in order to protect their wealth from the corrosive effects of inflation, can substitute them for goods or services that are probably less taxed at home. A negative sign is expected for all equations.

The size of the informal sector as a percentage of GDP: the variable is estimated by the MIMIC method (multiple causes multiple indicators). This method is based on the idea that the informal economy can be considered as an unobserved latent variable that is influenced by several causes and affects several macroeconomic variables. Like the agricultural sector, this sector is difficult to tax [33]. Thus, a negative relationship is expected between the size of the informal sector and the different rates of tax revenues.
The research uses annual data from 1996 to 2015 on the eight (08) WAEMU countries. The availability of data explains the choice of the research period. The data on GDP per capita, the share of agriculture as a \% of GDP, exports and imports, the share of natural resources in GDP and the inflation rate come from WB statistical data [39]. The size of the informal sector is taken from Medina et Schneider database [28]. The data on the different types of tax revenues come from ADB database [1]. Data on the quality of institutions are taken from Worldwide Governance Indicators, International Country Risk Guide and, Polity IV Project databases [20, 32, 40].

\subsection{Estimation Methods}

It should be stressed that preliminary tests are necessary in order to choose the appropriate estimation technique. In this respect, stationarity tests are carried out. These tests make it possible to avoid spurious regressions. For the present research, the test of Maddala and $\mathrm{Wu}$ as well as that of Choi are chosen for the following reasons $[13,26]$. On the one hand, first generation tests such as those of Maddala et $\mathrm{Wu}$ have limitations: they assume inter-individual independence of the residues and a heterogeneous character of the unit root.

Table 1. Unit root test results.

\begin{tabular}{|c|c|c|c|c|}
\hline \multirow{3}{*}{ Variables } & \multicolumn{4}{|l|}{ Niveau } \\
\hline & \multirow{2}{*}{ MW } & \multicolumn{3}{|l|}{ Choi } \\
\hline & & $\mathbf{Z}$ & $\mathbf{L}^{*}$ & Pm \\
\hline Total tax revenue in $\%$ GDP & $12.8662(0.6825)$ & $1.0160(0.8452)$ & $0.8555(0.8015)$ & $-0.5540(0.7102)$ \\
\hline Direct tax revenue \% GDP & $15.1020(0.5172)$ & $0.0104(0.5042)$ & $-0.0124(0.4951)$ & $-0.1588(0.5631)$ \\
\hline Domestic indirect tax revenue $\%$ GDP & $20.3229(0.2060)$ & $-0.2188(0.4134)$ & $-0.2593(0.3983)$ & $0.7642(0.2224)$ \\
\hline Trade tax revenue $\%$ GDP & $24.6430 *(0.0764)$ & $-1.713 * *(0.0433)$ & $-1.693 * *(0.0487)$ & $1.5279 *(0.0633)$ \\
\hline Polity2 & $16.8586(0.3948)$ & $-0.2976(0.3830)$ & $-0.3466(0.3653)$ & $0.1518(0.4397)$ \\
\hline WGI composite index & $18.8822(0.2748)$ & $0.7962(0.7870)$ & $0.8146(0.7902)$ & $0.5095(0.3052)$ \\
\hline ICRG composite index & $8.3421(0.8708)$ & $0.6861(0.7537)$ & $0.6780(0.7491)$ & $-1.0692(0.8575)$ \\
\hline GDP per capita & $2.0973(1.0000)$ & $3.3905(0.9997)$ & $3.2353(0.9988)$ & $-2.4577(0.9930)$ \\
\hline Share of agriculture in GDP & $21.8504(0.1481)$ & $-1.5714 *(0.0580)$ & $-1.4761 *(0.0735)$ & $1.0342(0.1505)$ \\
\hline Share of natural resources in GDP & $15.2549(0.5061)$ & $0.2886(0.6135)$ & $0.2312(0.5909)$ & $-0.1317(0.5524)$ \\
\hline Trade opening & $21.8945(0.1466)$ & $-0.2142(0.4152)$ & $-0.3944(0.3476)$ & $1.0420(0.1487)$ \\
\hline Inflation & $101.345 * * *(0.0000)$ & $-7.97 * * *(0.0000)$ & $-9.98 * * *(0.0000)$ & $15.08 * * *(0.0000)$ \\
\hline Informal sector & $19.7415(0.2321)$ & $0.0630(0.5251)$ & $-0.1021(0.4596)$ & $0.6614(0.2542)$ \\
\hline
\end{tabular}

Table 1. Continued.

\begin{tabular}{|c|c|c|c|c|c|}
\hline \multirow{3}{*}{ Variables } & \multicolumn{4}{|l|}{ Différence première } & \multirow{3}{*}{ Conclusion } \\
\hline & \multirow{2}{*}{ MW } & \multicolumn{3}{|l|}{ Choi } & \\
\hline & & $\mathbf{Z}$ & $\mathbf{L}^{*}$ & Pm & \\
\hline Total tax revenue in $\%$ GDP & $153.2849 * * *(0.0000)$ & $-10.423 * * *(0.0000)$ & $-15.114 * * *(0.0000)$ & $24.269 * * *(0.0000)$ & $\mathrm{I}(1)$ \\
\hline Direct tax revenue $\%$ GDP & $184.0682 * * *(0.0000)$ & $-11.731 * * *(0.0000)$ & $-18.15 * * *(0.0000)$ & $29.7105 * * *(0.0000)$ & I (1) \\
\hline Domestic indirect tax revenue \% GDP & $140.8126 * * *(0.0000)$ & $-9.9165 * * *(0.0000)$ & $-13.87 * * *(0.0000)$ & $22.0640 * * *(0.000)$ & I (1) \\
\hline Trade tax revenue $\%$ GDP & & & & & $\mathrm{I}(0)$ \\
\hline Polity2 & $94.2762 * * *(0.0000)$ & $-6.6843 * * *(0.0000)$ & $-8.868 * * *(0.0000)$ & $13.8374 * * *(0.0000)$ & I (1) \\
\hline ICRG composite index & $84.9679 * * *(0.0000)$ & $-6.4664 * * *(0.0000)$ & $-8.9156 * * *(0.0000)$ & $13.4117 * * *(0.0000)$ & I (1) \\
\hline GDP per capita & $68.0861 * * *(0.0000)$ & $-6.0134 * * *(0.0000)$ & $-6.6665 * * *(0.0000)$ & $9.2076 * * *(0.0000)$ & I (1) \\
\hline Share of agriculture in GDP & $118.9894 * * *(0.0000)$ & $-8.708 * * *(0.0000)$ & $-11.708 * * *(0.0000)$ & $18.2061 * * *(0.0000)$ & I (1) \\
\hline Share of natural resources in GDP & $108.0750 * * *(0.0000)$ & $-8.460 * * *(0.0000)$ & $-10.647 * * *(0.0000)$ & $16.2767 * * *(0.0000)$ & I (1) \\
\hline Trade opening & $171.6751 * * *(0.0000)$ & $-10.631 * * *(0.0000)$ & $-16.919 * * *(0.0000)$ & $27.5197 * * *(0.0000)$ & I (1) \\
\hline Inflation & & & & & $\mathrm{I}(0)$ \\
\hline Informal sector & $244.4201 * * *(0.0000)$ & $-13.753 * * *(0.0000)$ & $-24.102 * * *(0.0000)$ & $40.3794 * * *(0.0000)$ & I (1) \\
\hline
\end{tabular}

Notes: The values in brackets are the p-values. $* * *, * *$ and $*$ denote stationarity at the $1 \%, 5 \%$ and $10 \%$ thresholds respectively. I $(0)$ and I (1) denote the stationarity of the level and order 1 variable, respectively. 
On the other hand, second generation tests such as Choi tend to remove the independence hypothesis [19]. This test makes it possible to eliminate inter-individual correlations and possible deterministic tendency components. Choi recommends the Pm and $\mathrm{Z}$ tests for empirical analysis because they lead to better results, in terms of size and power, than the $\mathrm{L}^{*}$ test [13].

As shown in Table 1 above, out of a total of thirteen (13) variables, two variables (inflation and trade tax revenue) are stationary at level I (0) and the others are integrated at level I (1). So, there is a presumption of cointegration, i.e., the existence of a long-term relationship between the variables. To test this relationship, Pedroni's test is used [30]. This test takes into account heterogeneity through parameters that may differ between individuals. Such heterogeneity can be found both at the level of cointegration relationships and at the level of shortterm dynamics. Taking such heterogeneity into account is an advantage because in practice, it is rare that the cointegration vectors are identical from one individual to another in the panel.

According to the results presented in Table 2, four of Pedroni's seven statistics reject the null hypothesis of noncointegration between variables. There is therefore a longterm relationship between the variables.

Table 2. Results of panel cointegration tests for each type of tax revenue.

\begin{tabular}{|c|c|c|c|c|}
\hline & Total tax revenue & Direct tax revenue & Internal indirect tax revenue & Trade tax revenue \\
\hline & Intra dimension & & & \\
\hline Panel v-Statistic & $0.603049(0.2732)$ & $1.410097 *(0.0793)$ & $-1.061510(0.8558)$ & $0.142138(0.4435)$ \\
\hline Panel rho-Statistic & $-1.237893(0.1079)$ & $-0.982883(0.1628)$ & $0.304318(0.6196)$ & $-1.485658 *(0.0687)$ \\
\hline \multirow[t]{2}{*}{ Panel ADF-Statistic } & $-4.497 * * *(0.0000)$ & $-2.298722 * *(0.0108)$ & $-3.122963 * * *(0.0009)$ & $-2.965041 * * *(0.0015)$ \\
\hline & Inter Dimension & & & \\
\hline Group rho-Statistic & $0.625734(0.7343)$ & $0.447013(0.6726)$ & $0.918690(0.8209)$ & $-0.013891(0.4945)$ \\
\hline Group ADF-Statistic & $-5.960 * * *(0.0000)$ & $-2.458641 * * *(0.0070)$ & $-3.051341 * * *(0.0011)$ & $-2.008167 * *(0.0223)$ \\
\hline
\end{tabular}

Notes: Probability values are given in brackets. ${ }^{* * *}, * *$ and $*$ indicate rejection of the null hypothesis of non-cointegration at the $1 \%, 5 \%$ and $10 \%$ threshold respectively.

Following the various preliminary tests, the estimators Mean Group (MG), Dynamic Fixed Effects (DFE) and Pooled Mean Group (PMG), proposed by par Pesaran, Shin, and Smith, are indicated for the estimates. These methods allow the estimation of panel cointegration relationships [31]. The MG estimator does not impose any restrictions on the coefficients or on the estimated variances. The DFE estimator assumes that the parameters are identical across individuals. The PMG estimator considers that the model constant, as well as the short-term coefficients and error variances, may differ between individuals, but the long-term coefficients are constrained to be identical across all units.

The choice between these three estimators is made using the Hausman test. The Hausman tests carried out following the estimates indicate that the PMG estimator is more robust. The interpretations therefore focus on the results obtained using the PMG method.

\section{Result}

Here, we analyze descriptive statistics and estimation results.

\subsection{Descriptive Statistics}

Table 3, which provides descriptive statistics, indicates that the average total tax revenue is $14.97 \%$ GDP, which is below the minimum required $(20 \%)$ under multilateral surveillance of WAEMU countries. As for the quality of institutions, the average composite index shows a negative value, indicating a weak performance of the institutional environment in the Union.

Looking at the composition of tax revenues, the rate of direct, domestic indirect and trade tax revenue in the Union is, respectively, $3.34 \%, 4.08 \%$ and $4.83 \%$ of GDP. This means that, in the WAEMU zone, tax revenue from external trade is still dominant. This indicates a difficulty in making a successful fiscal transition in the zone. Does the quality of the institutions explain this situation? The following point analyses this question from an econometric point of view.

\subsection{Results of Estimates and Interpretations}

The following Table 4 reports the results of estimating the effect of institutional factors on the various tax revenue components using the PMG method.

Considering the total tax revenue equation, the results show positive and statistically significant coefficients at the $5 \%$ threshold for KKZ's governance quality composite index. This means that an improvement in the quality of institutions favors a better mobilization of overall tax revenues in WAEMU countries: a one-point improvement in the quality of WGI institutions leads to an increase in the total tax revenue by 2.014 percentage points. The results are robust because they do not depend on the indicator measuring the quality of institutions. A one-point increase in democratic quality (the polity2 index) improves the total tax revenue by 0.406 percentage points. Also, a one-point increase in the ICRG composite index improves the total tax revenue by 1.401 percentage points. These results corroborate those of Ndiaye and Keho, who argue that the weak fiscal performance of WAEMU countries is the result of poor institutional quality $[22,29]$. Therefore, improving institutional quality is crucial for increasing fiscal revenue in these countries. In fact, an institutional environment characterized by transparency in the management of public affairs, freedom of voting, press and 
expression, the possibility of denouncing the misconduct of leaders, accompanied by the possibility of losing power through a sanction vote by the citizens, improves the confidence of the population in government and consequently considerably encourages taxpayers to pay taxes. Moreover, a good capacity of a government to formulate sound policies and implement them, as well as respect by the state and citizens for the institutions governing their economic and social interactions, leads to efficient and effective tax administrations, which facilitates tax collection.

Table 3. Descriptive statistics.

\begin{tabular}{|c|c|c|c|c|c|}
\hline Variables & Observations & Average & Standard deviation & Minimum & Maximum \\
\hline Total tax revenue in $\%$ GDP & 151 & 14.96841 & 3.427483 & 7.578451 & 23.1909 \\
\hline Direct tax revenue \% GDP & 151 & 3.341651 & 1.032792 & 0.803091 & 5.496333 \\
\hline Domestic indirect tax revenue $\%$ GDP & 151 & 4.084032 & 2.482146 & 1.315078 & 10.54702 \\
\hline Trade tax revenue $\%$ GDP & 151 & 4.832342 & 2.148356 & 1.328237 & 11.94275 \\
\hline GDP per capita & 160 & 2.712512 & 0.2164734 & 2.202111 & 3.184867 \\
\hline Share of agriculture in GDP & 160 & 31.50087 & 9.931655 & 11.88239 & 61.41626 \\
\hline Share of natural resources in GDP & 160 & 9.643466 & 5.927427 & 2.42534 & 31.59078 \\
\hline Informal sector & 160 & 40.49325 & 6.270081 & 21.98 & 56.63 \\
\hline Inflation & 160 & 4.148106 & 8.109476 & -9.823833 & 80.89967 \\
\hline WGI composite index & 160 & $-2.47 \mathrm{e}-09$ & 1.000001 & -2.119982 & 2.255733 \\
\hline ICRG composite index & 140 & $8.62 \mathrm{e}-09$ & 1.000000 & -1.338143 & 2.505824 \\
\hline Polity2 & 160 & 2.88125 & 4.166914 & -6 & 8 \\
\hline
\end{tabular}

Source: Authors

From the equation for the direct tax revenue, it can be seen that a one-point increase in the composite WGI index is accompanied by an increase in the direct tax revenue of 0.463 percentage points. Similarly, a one-point increase in democratic quality (respectively a one-point increase in the ICRG composite index) leads to an increase in the direct tax revenue of 0.047 percentage points (respectively 0.594 percentage points). Thus, in WAEMU countries, good quality institutions lead to an increase in direct tax revenues. Addison and Levin reach the same result in their study of a set of 39 Sub-Saharan African countries covering the period from 1980 to 2005 [3]. According to them, an institutional environment characterized by a more democratic and peaceful political regime enjoys greater legitimacy and loyalty from taxpayers, which leads to a higher degree of voluntary compliance with taxation. This result is very important for WAEMU countries with very low direct tax revenues. In reality, the mobilization of this type of tax revenue requires a strong intrinsic motivation on the part of taxpayers to pay taxes, which in turn depends on the legitimacy, efficiency and credibility of the government [15]. Government legitimacy refers to the approval of government by citizens; government effectiveness refers to the government's ability to meet citizens' expectations; and government credibility refers to the predictability and sustainability of government actions.

With regard to the equation of domestic indirect tax revenue, the results indicate that an improvement in the quality of institutions allows for the mobilization of indirect domestic tax revenues. This result remains robust across the three (03) different measures of institutional quality. A one-point increase in the composite WGI index and the polity variable2 leads to an increase in indirect domestic tax revenues of 1.415 and 0.055 percentage points respectively. Also, a one-point increase in the ICRG composite index improves the domestic indirect tax revenue by 0.494 percentage points. This result is also crucial for WAEMU countries which, as part of fiscal transition, are particularly keen to increase this type of tax revenue. These results confirm those of the work of Alesina and Rodrik. Thus, for a successful fiscal transition in these countries, institutional reform is essential, including strong political will, as a country's tax system reflects its political institutions and a profound reform in the organization of tax administrations [4, 27].

As for the trade tax revenue equation, whatever the indicator used to measure the quality of institutions considered, the effect is insignificant. Mahdavi found the same results in his study of developing countries from 1973 to 2002 [27]. This means that the performance of institutional quality in the WAEMU space does not significantly improve the mobilization of trade tax revenues, which is understandable as long as these countries are engaged in the process of fiscal transition. Indeed, WAEMU countries are integrated into the global world and have therefore implemented policies that reduce barriers to trade. According to Chambas, trade opening policies in the framework of regional integration zones with the implementation of partnership agreements with the European Union (EU) have led to an average loss of about 30 per cent of the budget revenues of African countries [11]. In reality, at present in WAEMU countries, as in most developing countries, institutional reforms are aimed at reducing trade tax revenues, which explains the negative and insignificant effect of the quality of institutions on this type of tax revenue.

With regard to the control variables, overall, it appears that GDP per capita positively and significantly affects total and indirect domestic tax revenue, while it has a negative effect on direct tax revenue. Trade openness has a positive and significant effect on tax revenues, except for indirect domestic tax revenue. The share of agriculture has a positive and significant effect on all types of revenue except trade tax revenue. Inflation has a negative and significant effect on all types of tax revenues. The share of natural resources and the size of the informal sector show mixed results.

In sum, the results show that in the WAEMU zone, the 
quality of institutions positively and significantly affects all types of tax revenues except trade tax revenues.

Table 4. Long-term results of estimating the effect of institutional quality on different types of tax revenues (PMG).

\begin{tabular}{|c|c|c|c|c|c|c|}
\hline \multirow{2}{*}{$\begin{array}{l}\text { Variables } \\
\text { WGI composite index }\end{array}$} & \multicolumn{3}{|c|}{ Total tax revenue in \% GDP } & \multicolumn{3}{|c|}{ Rate of direct tax revenue in \% GDP } \\
\hline & $\begin{array}{l}2.01453^{* * *} \\
0\end{array}$ & & & $\begin{array}{l}0.46340^{* * *} \\
0\end{array}$ & & \\
\hline Polity2 & & $\begin{array}{l}0.40617 * * * \\
0\end{array}$ & & & $\begin{array}{l}0.04743 * * * \\
-0.001\end{array}$ & \\
\hline ICRG composite index & & & $\begin{array}{l}1.40189 * * * \\
0\end{array}$ & & & $\begin{array}{l}0.59415 * * * \\
0\end{array}$ \\
\hline GDP per capita & $\begin{array}{l}7.69003 * * * \\
0\end{array}$ & $\begin{array}{l}12.38538 * * * \\
0\end{array}$ & $\begin{array}{l}4.18934 * * * \\
0\end{array}$ & $\begin{array}{l}-1.2752 * * * \\
-0.002\end{array}$ & $\begin{array}{l}4.22445^{* * *} \\
0\end{array}$ & $\begin{array}{l}2.15531 * * * \\
-0.003\end{array}$ \\
\hline Share of agriculture in $\%$ GDP & $\begin{array}{l}0.16305 * * * \\
0\end{array}$ & $\begin{array}{l}0.29696^{* * *} \\
0\end{array}$ & $\begin{array}{l}-0.2902 * * * \\
0\end{array}$ & $\begin{array}{l}0.07592 * * * \\
0\end{array}$ & $\begin{array}{l}0.08710^{* * *} \\
-0.001\end{array}$ & $\begin{array}{l}-0.02999 \\
-0.142\end{array}$ \\
\hline $\begin{array}{l}\text { Share of natural resources in \% } \\
\text { GDP }\end{array}$ & $\begin{array}{l}0.08571^{* *} \\
-0.027\end{array}$ & $\begin{array}{l}0.08789 \\
-0.115\end{array}$ & $\begin{array}{l}0.02631 \\
-0.477\end{array}$ & $\begin{array}{l}-0.0752 * * * \\
0\end{array}$ & $\begin{array}{l}-0.02528 \\
-0.118\end{array}$ & $\begin{array}{l}0.13333 * * * \\
0\end{array}$ \\
\hline Trade opening & $\begin{array}{l}0.11211 * * * \\
0\end{array}$ & $\begin{array}{l}0.11465 * * * \\
0\end{array}$ & $\begin{array}{l}0.01729 \\
-0.223\end{array}$ & $\begin{array}{l}0.02931 * * * \\
-0.001\end{array}$ & $\begin{array}{l}0.00432 \\
-0.523\end{array}$ & $\begin{array}{l}0.02324 * * * \\
-0.001\end{array}$ \\
\hline Inflation & $\begin{array}{l}-0.19988 * * * \\
0\end{array}$ & $\begin{array}{l}-0.32105^{* * *} \\
0\end{array}$ & $\begin{array}{l}-0.1945 * * * \\
0\end{array}$ & $\begin{array}{l}-0.0142 * * * \\
0\end{array}$ & $\begin{array}{l}-0.1552 * * * \\
0\end{array}$ & $\begin{array}{l}-0.5809^{* * *} \\
-0.006\end{array}$ \\
\hline $\begin{array}{l}\text { Size of the informal sector in \% } \\
\text { GDP }\end{array}$ & $\begin{array}{l}0.30058^{* * *} \\
(0,001)\end{array}$ & $\begin{array}{l}0.42588 * * * \\
(0,000)\end{array}$ & $\begin{array}{l}-0.1572 * * * \\
(0,001)\end{array}$ & $\begin{array}{l}-0.1292 * * * \\
(0,000)\end{array}$ & $\begin{array}{l}-0.00594 \\
-0.709\end{array}$ & $\begin{array}{l}-0.03097 \\
-0.191\end{array}$ \\
\hline Constant & $\begin{array}{l}-16.0521^{* * *} \\
0\end{array}$ & $\begin{array}{l}-22.0344 * * * \\
0\end{array}$ & $\begin{array}{l}13.45342 * * * \\
-0.001\end{array}$ & $\begin{array}{l}3.97495 * * \\
-0.012\end{array}$ & $\begin{array}{l}-3.70534 * * \\
-0.013\end{array}$ & $\begin{array}{l}-1.5309 * * * \\
0\end{array}$ \\
\hline Return force & $\begin{array}{l}-0.54186^{* * *} \\
0\end{array}$ & $\begin{array}{l}-0.41677^{* * *} \\
0\end{array}$ & $\begin{array}{l}-0.7720 * * * \\
-0.001\end{array}$ & $\begin{array}{l}-0.4930 * * * \\
0\end{array}$ & $\begin{array}{l}-0.36735 * * \\
-0.015\end{array}$ & $\begin{array}{l}-0.5158 * * * \\
0\end{array}$ \\
\hline $\begin{array}{l}\text { Number of observations } \\
\text { Hausman test }\end{array}$ & $\begin{array}{l}137 \\
(1.0000)^{* * *}\end{array}$ & $\begin{array}{l}137 \\
(1.0000) * * *\end{array}$ & $\begin{array}{l}122 \\
(0.9980) * * *\end{array}$ & $\begin{array}{l}137 \\
(1.0000)^{* * *}\end{array}$ & $\begin{array}{l}143 \\
(0.8002)^{* * *}\end{array}$ & $\begin{array}{l}128 \\
(0.9872)^{* * *}\end{array}$ \\
\hline
\end{tabular}

Table 4. Continued.

\begin{tabular}{|c|c|c|c|c|c|c|}
\hline \multirow{2}{*}{$\begin{array}{l}\text { Variables } \\
\text { WGI composite index }\end{array}$} & \multicolumn{3}{|c|}{ Rate of domestic indirect tax revenue in \% GDP } & \multicolumn{3}{|c|}{ Rate of trade tax revenue in \% GDP } \\
\hline & $\begin{array}{l}1.41517 * * * \\
0\end{array}$ & & & $\begin{array}{l}-0.11341 \\
-0.674\end{array}$ & & \\
\hline Polity2 & & $\begin{array}{l}0.05534 * * * \\
0\end{array}$ & & & $\begin{array}{l}-0.01583 \\
(0,461)\end{array}$ & \\
\hline ICRG composite index & & & $\begin{array}{l}0.49421 * * * \\
0\end{array}$ & & & $\begin{array}{l}1.00723 \\
-0.236\end{array}$ \\
\hline GDP per capita & $\begin{array}{l}2.10563 * * * \\
-0.004\end{array}$ & $\begin{array}{l}5.53413 * * * \\
0\end{array}$ & $\begin{array}{l}2.39710 * * * \\
0\end{array}$ & $\begin{array}{l}-0.30783 \\
-0.673\end{array}$ & $\begin{array}{l}-0.90047 \\
-0.516\end{array}$ & $\begin{array}{l}0.01128 \\
-0.994\end{array}$ \\
\hline Share of agriculture in $\%$ GDP & $\begin{array}{l}0.04844 * * * \\
0\end{array}$ & $\begin{array}{l}0.02812 * * * \\
0\end{array}$ & $\begin{array}{l}0.03682 * * \\
-0.039\end{array}$ & $\begin{array}{l}-0.02891 * \\
-0.097\end{array}$ & $\begin{array}{l}-0.00337 \\
-0.799\end{array}$ & $\begin{array}{l}-0.00025 \\
-0.988\end{array}$ \\
\hline $\begin{array}{l}\text { Share of natural resources in \% } \\
\text { GDP }\end{array}$ & $\begin{array}{l}0.11991 * * * \\
0\end{array}$ & $\begin{array}{l}0.09420 * * * \\
-0.009\end{array}$ & $\begin{array}{l}-0.1280 * * * \\
0\end{array}$ & $\begin{array}{l}-0.14861 * * * \\
-0.001\end{array}$ & $\begin{array}{l}-0.29934 * * * \\
0\end{array}$ & $\begin{array}{l}-0.494 * * * \\
0\end{array}$ \\
\hline Trade opening & $\begin{array}{l}-0,01074 \\
-0.326\end{array}$ & $\begin{array}{l}0,01294 \\
-0.146\end{array}$ & $\begin{array}{l}0.01969 * * * \\
0\end{array}$ & $\begin{array}{l}0.07416 * * * \\
0\end{array}$ & $\begin{array}{l}0.04767 * * * \\
-0.004\end{array}$ & $\begin{array}{l}0.02401 \\
-0.104\end{array}$ \\
\hline Inflation & $\begin{array}{l}-0.0203 \\
-0.402\end{array}$ & $\begin{array}{l}-0.06869 * * * \\
0\end{array}$ & $\begin{array}{l}0.0152 \\
-0.425\end{array}$ & $\begin{array}{l}-0.08939 * * \\
-0.019\end{array}$ & $\begin{array}{l}-0.15250 * * * \\
-0.001\end{array}$ & $\begin{array}{l}-0.205^{* * *} \\
-0.002\end{array}$ \\
\hline Size of the informal sector in $\%$ & $-0.2584 * * *$ & $-0.10592 * * *$ & -0.02938 & $0.26646^{* * *}$ & 0.05157 & -0.09703 \\
\hline GDP & 0 & 0 & -0.436 & 0 & -0.159 & -0.203 \\
\hline Constant & $\begin{array}{l}3.16230 * * * \\
-0.0005\end{array}$ & $\begin{array}{l}-4.40189 * * \\
-0.02\end{array}$ & $\begin{array}{l}-1.3417 \\
-0.275\end{array}$ & $\begin{array}{l}-3.20839 * * \\
-0.02\end{array}$ & $\begin{array}{l}2.12997 * * \\
-0.05\end{array}$ & $\begin{array}{l}4.68165^{* *} \\
-0.022\end{array}$ \\
\hline Return force & $\begin{array}{l}-0.4587 * * * \\
-0.009\end{array}$ & $\begin{array}{l}-0.52382 * * \\
-0.02\end{array}$ & $\begin{array}{l}-0.50138^{*} \\
-0.071\end{array}$ & $\begin{array}{l}-0.51179 * * \\
(., 023)\end{array}$ & $\begin{array}{l}-0.36275 * * \\
-0.031\end{array}$ & $\begin{array}{l}-0.387 * * * \\
-0.009\end{array}$ \\
\hline $\begin{array}{l}\text { Number of observations } \\
\text { Hausman test }\end{array}$ & $\begin{array}{l}137 \\
(0.8392) * * *\end{array}$ & $\begin{array}{l}137 \\
(0.9951)^{* * *}\end{array}$ & $\begin{array}{l}116 \\
(0.8408)^{* * *}\end{array}$ & $\begin{array}{l}137 \\
(0.9962) * * *\end{array}$ & $\begin{array}{l}143 \\
(0.9910)^{* * *}\end{array}$ & $\begin{array}{l}122 \\
(0.9946) * * *\end{array}$ \\
\hline
\end{tabular}

Notes: p-values are reported in brackets. $* * * ; *$ and $*$ indicate significance at $1 \%, 5 \%$ and $10 \%$ respectively. The Return force is negative and significant in all estimates so the model is valid

\section{Conclusion}

The objective of this essay is to analyze the effect of the quality of institutions on different types of tax revenues, in particular on total tax revenue, direct tax revenue, domestic indirect tax revenue and trade tax revenue. The econometric analysis used the PMG estimator over the period from 1996 to
2015. The results of the estimates show that in the WAEMU zone, the quality of institutions has a positive and significant effect on all types of tax revenue except for trade tax revenue. These results are robust because they do not change according to the different indicators used to measure the quality of institutions. This means that an adequate institutional framework, by strengthening the willingness of taxpayers to 
pay taxes and the efficiency of tax administrations in collecting taxes, fundamentally improves the mobilization of total, direct and indirect domestic tax revenues. Moreover, at present in WAEMU countries, as in most developing countries, fiscal transition reforms are aimed at reducing commercial tax revenues, which explains the negative effect of the quality of institutions on this type of tax revenue. The insignificance of the effect of commercial tax revenues reflects the lack of efficiency in the implementation of these reforms.

In the light of these results, this paper suggests that WAEMU countries should strengthen institutional arrangements aimed at improving the mobilization of domestic tax revenues (direct and indirect) and reducing gate revenues in order to achieve a successful fiscal transition. In practice, this means broadening the internal tax base through the establishment of a single land registry file to better monitor the mobilization of land and property revenues, a directory of informal sector jobs and taxpayers, a tax on cash crops and a tax on agricultural land rentals.

\section{Appendix}

\section{Appendix 1: KKZ Governance Indicators and Construction of a Composite Index}

KKZ's governance indicators range from -2.5 , corresponding to a very poor quality of governance, to +2.5 , reflecting a very good quality of governance. KKZ presents them as follows:

Freedom of Expression and Accountability: Opportunity for a country's citizens to participate in the appointment of government members. This indicator includes indicators measuring different aspects of the political process, civil liberties, political rights and media independence.

Political Stability: Perceptions of the likelihood that an incumbent government will be destabilized or overthrown by possible unconstitutional and/or violent means, including domestic violence and terrorism.

Government Effectiveness: Perceptions of the quality of public services provided and administration, the competence of civil servants, the independence of the civil service from political pressure, and the credibility of the government's commitment to political leaders.

Quality of regulation: Perceptions of the government's ability to formulate and implement sound policies and regulations that enable and promote private sector development.

Rule of Law: A society's ability to create an environment in which fair and predictable rules provide the basis for economic and social interactions in the protection of property rights. This indicator covers perceptions of the incidence of crime, the effectiveness and predictability of the judiciary, and the ability to enforce and respect contracts.

Corruption Control: Perceptions of corruption defined as the abuse of public power for private gain. It covers both petty corruption, grand corruption, and capture of the state.

Construction of the composite index of institutional quality from the KKZ indicators using the Principal Component Analysis (PCA) method.

PCA is a factorial method of reducing the number of variables used to describe a phenomenon. To do this:

First of all, it is necessary to ensure the factorizability of the initial variables, i.e., the heterogeneity of the data. To carry out this verification, three methods exist:

The analysis of the correlation matrix, which consists of examining the correlation coefficients. When these are quite high (or when the correlation matrix determinant is low) it can be assumed that the analysis is relevant.

Bartlett's test of sphericity consists in detecting to what extent the correlation matrix calculated on the data (observed matrix) diverges significantly from the identity matrix (under the null hypothesis Ho). The rejection of Ho (low critical probability, i.e., $<0.05)$ means that the variables are correlated and therefore further analysis is relevant.

The Kaiser-Meyer-Olkin test (KMO), which assesses the extent to which the selected set of variables is a coherent set. When the KMO index is below 0.5 , the solution is unacceptable.

Table 5: Factorability test.

\begin{tabular}{lll}
\hline Determinant & Bartlett & KMO \\
\hline 0.005 & 831.858, P-value $=0.000$ & 0.860 \\
\hline
\end{tabular}

Source: Authors

The results of the previous table indicate that the data are sufficiently heterogeneous to allow for the extraction of key components. Thus, the main components obtained are as follows:

Table 6: Results of principal components analysis.

\begin{tabular}{|c|c|c|c|c|c|c|}
\hline & PCA1 & PCA2 & PCA3 & PCA4 & PCA5 & PCA6 \\
\hline Corruption Control & 0,4111 & $-0,3931$ & 0,3865 & 0,3689 & 0,5742 & $-0,2476$ \\
\hline Government Effectiveness & 0,43 & $-0,2468$ & $-0,3031$ & 0,4731 & $-0,6437$ & $-0,1552$ \\
\hline Political Stability & 0,3023 & 0,8159 & 0,3639 & 0,3148 & $-0,0704$ & 0,0804 \\
\hline Quality of regulation & 0,4346 & $-0,256$ & 0,3088 & $-0,3318$ & $-0,173$ & 0,7143 \\
\hline Rule of Law & 0,4437 & 0,1105 & 0,0584 & $-0,6554$ & $-0,1135$ & $-0,5875$ \\
\hline Freedom of Expression and Accountability & 0,4111 & 0,2027 & $-0,7263$ & $-0,0372$ & 0,4563 & 0,2297 \\
\hline Own values & 4,35794 & 0,799419 & 0,363405 & 0,201525 & 0,15411 & 0,123601 \\
\hline$\%$ variance & 0,7263 & 0,1332 & 0,0606 & 0,0336 & 0,0257 & 0,0206 \\
\hline$\%$ Cumulative & 0,7263 & 0,8596 & 0,9201 & 0,9537 & 0,9794 & 1 \\
\hline
\end{tabular}

Source: Authors 
Next, extract the relevant main component (s). Analysis of the previous table reveals that the first component (PCA1) alone explains more than $50 \%$ of the total variance of the sample (i.e., exactly $72.63 \%$ ). Furthermore, the eigenvalue associated with this component is greater than 1 , so PCA1 is used for the rest of the analysis.

Then, the specific weights are calculated from the rotation matrix and the explained variance of PCA1: the rotation matrix provides the coefficients related to the interactions between the variables. The weights are calculated by squaring these coefficients divided by the variance of PCA1.

Finally, the composite index is expressed as a linear combination of the initial variables of interest affected by their respective weights.

\section{Appendix 2: Presentation of ICRG Indicators}

Stability of government (12 points): This measures the ability of the government to carry out the programmes it has planned and to remain in place. It is measured using three sub-indicators rated between 0 and 4 :

Unit of government

Legislative power

Support from the population

Socio-economic conditions (12 points): These measure the socio-economic pressures that can constrain government actions or trigger social tensions. This indicator is obtained by summing 3 sub-indicators rated between 0 and 4 :

Unemployment

The confidence of the population

Poverty

Investment profile (12 points): It is an assessment of factors affecting investment risk that are not covered by other components of political, economic and financial risk The risk rating assigned is the sum of three subcomponents, each with a maximum score of four points and a minimum score of 0 points. A score of 4 points is equivalent to a very low risk and a score of 0 points to a very high risk:

Viability of the contract / expropriation

Repatriation of profits

Late payments

Internal conflicts (12 points): They measure political violence in the country and its impact on governance. This indicator is obtained by summing three sub-indicators rated between 0 and 4 :

Civil war/threatening situation

Terrorism/Political violence

Civil conflicts

External conflicts (12 points): Measures the impact of foreign pressure on government actions. It is measured using three sub-indicators rated between 0 and 4 :

War

Border conflict

Foreign pressure

Control of corruption ( 6 points): The corruption indicator measures the extent to which public power is exercised for private enrichment, as well as the control of elites and interests over the state. A low score indicates a high level of corruption in the public administration that results in bribery, tax fraud and evasion, and laxity and favoritism in controls and licensing.

Military influence on political life (6 points): Evaluates the involvement of the military in the political life of the country. This can diminish democratic accountability.

Religious tensions (6 points): Religious tensions can arise from the domination of society and/or governance by a single religious group that seeks to replace civil law with religious law and to exclude other religions from the political and/or social process; the desire of a single religious group to dominate governance; the suppression of religious freedom; the desire of a religious group to express its own identity, separate from the country as a whole. The risks involved in these situations range from inexperienced people imposing inappropriate policies to civil war and civil dissent.

Law and order (6 points): Measures the strength and independence of the judicial system, the degree of citizens' compliance with law and order, including the quality of property rights, police and courts, and the risk of crime. This indicator is obtained by summing two sub-indicators rated between 0 and 3:

The law: assesses the strength and independence of the judiciary.

Order: evaluates the population's respect for the law.

A country can have a high rating of 3 in terms of the judicial system but a low rating of 1 if there is a high crime rate.

Ethnic tensions (6 points): Assesses the degree of racial tensions and diverse nationalities.

Democratic accountability (6 points): Measures how the government responds to its people. Democracy gives the different actors in society the possibility to exert pressure on the state, or even to sanction the state in case of failure. The principle of democratic accountability makes the state accountable to its citizens for its actions. It has an obligation to be accountable to its citizens for the management of its affairs. The maximum number of points is awarded to the country based on free and fair elections as mentioned in the constitution: it is the alternation of democracies. The minimum points are awarded to the country in which the leadership of the state is a single individual: this is autocracy.

Quality of bureaucracy (4 points): Measures the ability of the administration to conduct day-to-day business without major policy changes or disruption to public services.

NB: A high score indicates better institutional quality.

\section{References}

[1] African Development Bank database (ADB, 2018). 
[2] Agbeyegbe, T. D., Stotsky, J., \& Wolde Mariam, A. (2006). Trade liberalization, exchange rate changes, and tax revenue in Sub-Saharan Africa. Journal of Asian Economics 17 (2006), 261-284.

[3] Addison, T., \& Levin, J. (2012). The Determinants of Tax Revenue in Sub-Saharan Africa. Journal of International Development; https://www.semanticscholar.org.

[4] Alesina, A., \& Rodrik, D. (1994). Distributive politics and economic growth. Quarterly Journal of Economics 109, no. 2, 465-490.

[5] Attila, G., Chambas, G., \& Combes, J.-L. (2009). Corruption et mobilisation des recettes publiques: une analyse économétrique. Recherches Economiques de Louvain, Louvain Economic Review 75 (2), 229-268.

[6] Auty, R. M. (1993). Resource abundance and economic development: improving the performance of resource rich countries. London: Taylor \& Francis e-Library.

[7] Bahl, R. W. (1971, November). A Regression Approach to Tax Effort and Tax Ratio Analysis. Staff Papers - International Monetary Fund, Vol. 18, No. 3, pp. 570-612.

[8] Baunsgaard, T., \& Keen, M. (2010). Tax revenue and (or?) trade liberalization. Journal of Public Economics 94, 563577 .

[9] Botlhole. (2010). Tax effort and the determinants of tax ratio in sub-sahara africa. International Conference On Applied Economics (ICOAE), pp. 101-113.

[10] Buchanan, J. M., \& Wagner, R. E. (1977). Democracy in Deficit. New-York: Academic Press.

[11] Chambas, G. (2005). TVA et transition fiscale en Afrique: les nouveaux enjeux. Afrique contemporaine ( $\left.n^{\circ} 215\right)$, pp. 181194

[12] Chelliah, R. J. (1971, July). Trends in Taxation in Developing Countries. Staff Papers - International Monetary Fund, Vol. 18, No. 2, pp. 254-331.

[13] Choi, I. (2002). Combination Unit Root Tests for CrossSectionally Correlated Panels. http://hdl.handle.net/1783.1/129.

[14] Diarra, S. (2012, Décembre 04). Chocs et Mobilisation des Recettes Publiques dans les Pays en Développement. Economies et finances. Université d'Auvergne - ClermontFerrand I.

[15] Fauvelle-Aymar, C. (1999). The Political and Tax Capacity of Government in Developing Countries. Kyklos. Vol. 52, 391413.

[16] Heller, P. S. (1975). A Model of Public Fiscal Behavior in Developing Countries: Aid, Investissement and Taxation. The American Economic Review, 429-445.

[17] Hettich, W., \& Winer, S. (1984). A positive model of tax structure. Journal of Public Economics 24, 67-87.

[18] Hettich, W., \& Winer, S. (1985). The Economic and Political Foundations of Tax Structure. Centre for the Economic Analysis of Property Rights. Economics and Law Workshop Papers, 85-05. London, ON: Department of Economics, University of Western Ontario.

[19] Hurlin, C., \& Mignon, V. (2005). Une Synthèse des Tests de
Racine Unitaire sur Données de Panel. Université d'Orléans; Université Paris $X$.

[20] International Country Risk Guide database (ICRG, 2016)

[21] Karimi, M., Kaliappan, S. R., Ismail, N. W., \& Hamzah, H. Z. (2016). The Impact of Trade Liberalization on Tax Structure in Developing Countries. Procedia Economics and Finance 36, 274-282.

[22] Keho, Y. (2015). Institutions, Economic Structure and Tax Revenue in UEMOA Countries: A Pool Mean Group Analysis. Journal of Empirical Economics Vol. 4, No. 4, pp. 216-230.

[23] Kenny, L. W., \& Winer, S. L. (2006). Tax Systems in the World: An Empirical Investigation into the Importance of Tax Bases, Administration Costs, Scale and Political Regime. International Tax and Public Finance, 13, 181-215.

[24] Lotz, J. R., \& Morss, E. R. (1967). Measuring "Tax Effort" in Developing Countries. Staff Papers - International Monetary Fund, Vol. 14, No. 3, 478-499.

[25] Lotz, J. R., \& Morss, E. R. (1970, April). A Theory of Tax Level Determinants for Developing Countries. Economic Development and Cultural Change Vol. 18, No. 3, pp. 328341.

[26] Maddala, G., \& Wu, S. (1999). A Comparative Study of Unit Root Tests with Panel. Oxford Bulletin of Economics and Statistics, special issue, 631-652.

[27] Mahdavi, S. (2008). The level and composition of tax revenue in developing countries: Evidence from unbalanced panel data International Review of Economics and Finance 17, pp. 607617.

[28] Medina, L., \& Schneider, F. (2018). Shadow economies around the world: What did we learn over the last 20 years? IMF Working Paper.

[29] Ndiaye, M. B., \& Korsu, R. D. (2014). Tax effort in ECOWAS countries. Regional Economic Integration in West Africa, 137158 .

[30] Pedroni, P. (1999). Critical Values for Cointégration Tests in Heterogenous Panels with Multiple Regressors. Oxford Bulletin of Economics and Statistics, S1, 61, 653-670.

[31] Pesaran, M. H., Shin, Y., \& Smith, P. R. (1999). Pooled Mean Group Estimation of Dynamic Heterogeneous Panels. Journal of American Statistical Association 94 (446), 621-634.

[32] Polity IV Project database (2018).

[33] Schneider, F., \& Enste, D. (2000). Shadow Economies: Size, Causes and Consequences. Journal of Economic Literature 38 (1), 77-114.

[34] Shin, K. (1969, May). International Difference in Tax Ratio. The Review of Economics and Statistics, Vol. 51, No. 2, pp. 213-220.

[35] Stotsky, J. G., \& WoldeMariam, A. (1997). Tax Effort in SubSaharan Africa. International Monetary Fund (IMF) Working Paper No 107.

[36] Tanzi, V., \& Davoodi, H. R. (2000). Corruption, growth, and public finance. IMF Working Paper WP/00/182 Washington D.C.: International. 
[37] Wintrobe, R. (1990). The tinpot and the totalitarian: An economic theory of dictatorship. The american political science review, vol 84, number 3, 849-872.

[38] Wintrobe, R. (2002). Dictatorship. University of Western Ontario.
[39] World Development Indicators database (2018).

[40] Worldwide Governance Indicators database (2018). 